Original Research Article

\title{
Pattern of cutaneous adverse drug reactions at a tertiary care hospital in southern India
}

\author{
Babu L. N. ${ }^{1}$, Carounanidy Udayashankar ${ }^{2 *}$, Kavita Vasudevan P. ${ }^{3}$, Sivagnanam G. ${ }^{1}$
}

\begin{abstract}
${ }^{1}$ Department of Pharmacology
${ }^{2}$ Department of Dermatology,

${ }^{3}$ Department of Community

Medicine, Indira Gandhi

Medical College and Research

Institute, Puducherry, India
\end{abstract}

Received: 18 January 2017

Accepted: 27 January 2017

\section{*Correspondence to:}

Dr. Carounanidy Udayashankar,

Email: udayderm@yahoo.com

Copyright: (c) the author(s), publisher and licensee Medip Academy. This is an openaccess article distributed under the terms of the Creative Commons Attribution NonCommercial License, which permits unrestricted noncommercial use, distribution, and reproduction in any medium, provided the original work is properly cited.

\begin{abstract}
Background: The objective of the study was to assess the pattern of cutaneous adverse drug reactions reported by active surveillance to the Pharmacovigilance center of a tertiary care hospital in southern india, and also to establish the drugs causing the same and observe the age wise and gender based incidence of such reactions.

Methods: The cutaneous ADRs (CADRs) reported to the Pharmacovigilance center of the institution were analysed retrospectively during the period of March 2013 to December 2015. The various pattern of skin reactions and the most frequent drugs causing the same were established. An age wise and gender based incidence of CADRs and drugs causing them were also reported.

Results: A total of 293 cases were taken for analysis. The male female ratio was $0.89-1$.in our study. Among the age wise distribution of CADRs, 57(19.4\%) were seen in paediatric, $194(66.2 \%)$ in adults and 33(11.2\%) in geriatric age groups. The most frequent drugs to cause the CADRs were antimicrobials $183(62.4 \%)$ followed by NSAIDs $38(12.9 \%)$ and antacids $17(5.8 \%)$.Among the skin reactions urticaria/ angioedema was the most common 109(37.2\%) followed by generalised pruritis $57(19.5 \%$ ) and fixed drug eruption $37(12.6 \%)$. In all the age groups and both the sexes urticaria/angioedema and generalised pruritis were the leading skin reactions observed.

Conclusions: As CADRs are the most common ADRs among others, it is prudent to monitor them closely, as any change in pattern with older or newer agents can alert the health care personnel in instituting the appropriate prescription patterns, which can overall impact the quality of health care positively.
\end{abstract}

Keywords: Antimicrobials, Cutaneous adverse drug reaction, Pharmacovigilance

\section{INTRODUCTION}

Adverse drug reaction (ADR) is defined as "an appreciably harmful or unpleasant reaction, resulting from an intervention related to the use of a medicinal product, which predicts hazard from future administration and warrants prevention or specific treatment, or alteration of the dosage regimen, or withdrawal of the product." ADRs are seen in increasing numbers in patients both hospitalized, and in those on outpatient care. $^{2-6}$ It is also well known that ADRs contribute significantly to hospital admissions. ${ }^{7}$ ADRs as such is a cause of significant economic burden because it has been proven that hospitalization cost of patients who experience ADRs is comparatively more, than their counterparts who don't. ${ }^{8}$ It is also a significant burden economically to health care providers as well. ${ }^{9,10}$ Many studies have shown that cutaneous drug reactions are one of the most frequently encountered ADRs during patient care. $^{11,12}$ Since there is an advent of newer drug molecules periodically and change in treatment protocols, it is prudent to evaluate the cutaneous ADRs (CADRs) continually. ${ }^{13}$ Information obtained through such studies can give inputs on those ADRs that can be avoided with an increase in the quality of health care, apart from bringing down the costs involved in their management. ${ }^{14}$ The purpose of the current study is to elicit the pattern of CADRs, the drugs responsible and the age and gender based incidence of such reactions, in patients treated at a public tertiary care hospital in the southern part of India. 


\section{METHODS}

A retrospective analysis of the CADRs retrieved from the Pharmacovigilance center database reported by active surveillance was carried out. The data pertains to the period from March 2013 to December 2015. The CADRs obtained so were confirmed by a team consisting of a senior dermatologist and pharmacologists.

The CADRs were grouped as certain, probable, possible, unlikely, unclassified, and unclassifiable based on the WHO causality assessment criteria. Only those CADRs classified as certain, probable and possible were included in this study. The pattern of CADRs and the drugs causing them, as well as the age and gender wise incidence of CADRs were analysed from the above mentioned data.

The data was entered in MS excel and analyzed using SPSS v20.0. The data was summarized using means and proportions.

\section{RESULTS}

During the above said period a total of 510 ADRs were reported, of which 388 (76.08\%) were CADRs. Among these CADRs, only 293 (75.5\%) were taken for analysis, as they satisfied the above mentioned WHO criteria (Figure 1).

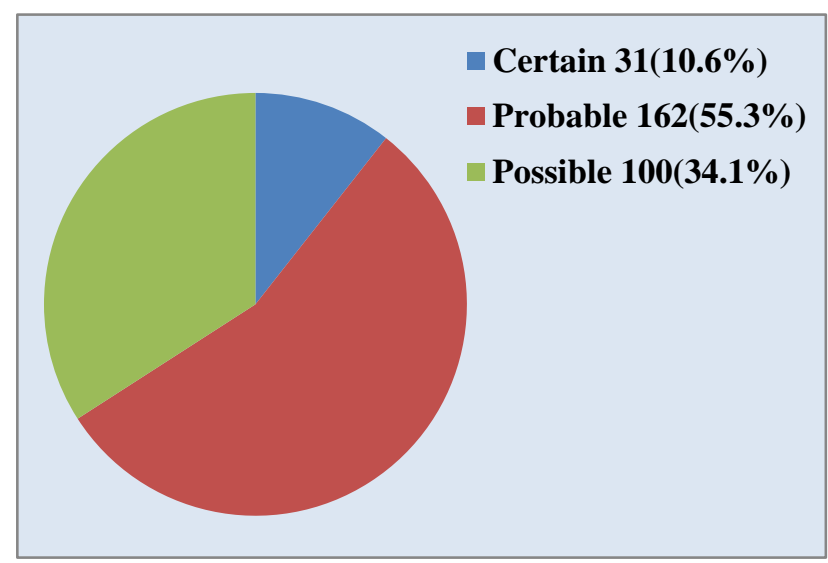

Figure 1: Distribution of CADRs as per WHO causality criteria.

Table 1: Demographic variables.

\begin{tabular}{|ll|}
\hline Sample size $(\mathbf{N}=293)$ & \\
\hline Male: Female & $135(47.2 \%): 151(52.7 \%)$ \\
\hline \multirow{2}{*}{ Age $^{€}$} & Paediatric 57 (20.07\%) \\
\hline & Adult 194 (68.3\%) \\
\hline & Geriatric 33(11.61\%) \\
\hline
\end{tabular}

* Missing data $=7 ; €$ Missing data $=9$

Among these 135 were seen in males, 151 were seen in females. They were grouped into paediatric (0-18), adult
(19-59) and geriatric (60 and >) age groups. Most of the CADRs were reported in the adult age group (Table 1).

Among the drug groups, antimicrobials were the most frequent to cause CADRs- $183(62.4 \%)$ (Table 2), followed by NSAIDs- $38(12.9 \%)$ and antacids- 17 $(5.8 \%)$. Among the antimicrobials, ciprofloxacin was the most frequent- 46 cases, followed by cefotaxime -23 cases and ceftriaxone- 21 cases. Among NSAIDs, CADRs were most frequently caused by diclofenac- 21 cases, followed by paracetamol- 7 cases.

Table 2: Frequent drug groups and drugs causing CADRs.

\begin{tabular}{|llll|}
\hline No. Drug group & $\begin{array}{l}\text { No. of } \\
\text { cases }(\%)\end{array}$ & $\begin{array}{l}\text { Most frequent } \\
\text { drugs-Nos. }\end{array}$ \\
\hline 1 & Antimicrobials & $\begin{array}{l}183 \\
(62.4 \%)\end{array}$ & $\begin{array}{l}\text { Ciprofloxacin 46 } \\
\text { Ceftriaxime 23 } 21 \\
\text { Cotrimoxazole 20 } \\
\text { Doxycycline 12 }\end{array}$ \\
\hline 2 & NSAIDs & $\begin{array}{l}\text { Diclofenac 21 } \\
(12.9 \%)\end{array}$ & $\begin{array}{l}\text { Paracetamol 7 } \\
\text { Aspirin 3 }\end{array}$ \\
\hline 3 & Antacids & $17(5.8 \%)$ & $\begin{array}{l}\text { Ranitidine 13 } \\
\text { Pantoprazole 3 }\end{array}$ \\
\hline 4 & Anesthetics & $9(3 \%)$ & Lignocaine 9 \\
\hline 5 & Antiepileptics & $8(2.7 \%)$ & $\begin{array}{l}\text { Carbamazepine 4 } \\
\text { Phenytoin 4 }\end{array}$ \\
\hline
\end{tabular}

A total of 20 different CADRs were observed in our study (Table 3). Of these the most common were urticaria/angioedema-109 (37.2\%), followed by generalised pruritis-57 (19.5\%), fixed drug eruption-37 $(12.6 \%)$, local reaction-35 (11.9\%), morbiliform rash-22 (7.5\%) and Stevens-Johnson Syndrome-6 (2\%). In all the above CADRs, antimicrobials were the most common causative agents followed by NSAIDs. However among local reactions and morbiliform rash antimicrobials were followed by antacids and antivirals as the most common causative agents respectively. With regard to Stevens Johnson syndrome-6 (2\%) the leading causative agents were antiepileptics followed by antimicrobials. Erythema multiforme-6 (2\%) cases were caused by antimicrobials.

In the age and sex wise distribution of ADRs (Table 4), again it was found that urticaria/angioedema were the most common CADRs followed by generalised pruritis. The most common drugs to cause such reactions were again found to be antimicrobials.

\section{DISCUSSION}

CADRs are the most common ADRs when compared with the prevalence of other ADRs. ${ }^{12}$ The cost involved in their management is significantly more for both the patients and health care providers. 
Table 3: CADRs and causative agents.

\begin{tabular}{|c|c|c|c|c|}
\hline No. & Cutaneous ADR & No $(\%)$ & \multicolumn{2}{|c|}{ Frequent Drug group Nos: Frequent Drugs } \\
\hline 1 & Urticaria/Angioedema & $109(37.2)$ & $\begin{array}{l}\text { Antimicrobials 57: } \\
\text { NSAIDs 19: } \\
\text { Antacids 8: }\end{array}$ & $\begin{array}{l}\text { Ceftriaxone, Ciprofloxacin, Cotrimoxazole } \\
\text { Diclofenac, Ibuprofen, Paracetamol } \\
\text { Ranitidine, Pantoprazole }\end{array}$ \\
\hline 2 & Generalised Pruritis & $57(19.5)$ & $\begin{array}{l}\text { Antimicrobials 42: } \\
\text { NSAIDs 6: } \\
\text { Antacids 4: }\end{array}$ & $\begin{array}{l}\text { Ciprofloxacin, Ceftriaxone, Cefotaxim } \\
\text { Paracetamol, Diclofenac } \\
\text { Ranitidine }\end{array}$ \\
\hline 3 & Fixed Drug Eruption & $37(12.6)$ & $\begin{array}{l}\text { Antimicrobials 23: } \\
\text { NSAIDs 8: }\end{array}$ & $\begin{array}{l}\text { Cotrimoxazole, Doxycycline, Amoxycillin } \\
\text { Diclofenac, Paracetamol }\end{array}$ \\
\hline 4 & Local Reaction & $35(11.9)$ & $\begin{array}{l}\text { Antimicrobials 28: } \\
\text { Antacids 4: }\end{array}$ & $\begin{array}{l}\text { Ciprofloxacin, Cloxacillin, Cefazolin } \\
\text { Ranitidine }\end{array}$ \\
\hline 5 & Morbiliform Rash & $22(7.5)$ & $\begin{array}{l}\text { Antimicrobials 17: } \\
\text { Antiviral 2: }\end{array}$ & $\begin{array}{l}\text { Cefotaxim, Ampicillin, Ciprofloxacin } \\
\text { Acyclovir, ART }\end{array}$ \\
\hline 6 & Stevens- Johnson Syndrome & $6(2)$ & $\begin{array}{l}\text { Antiepileptic 4: } \\
\text { Antimicrobials 2: }\end{array}$ & $\begin{array}{l}\text { Carbamazepine, Phenytoin } \\
\text { INH, Doxycycline }\end{array}$ \\
\hline 7 & Erythema Multiforme & $6(2)$ & Antimicrobials 6: & Doxycycline, Cefixime, Cotrimoxazole \\
\hline 8 & Morbiliform Eruption & $3(1)$ & Antimicrobials 6: & Doxycycline, Cotrimoxazole \\
\hline 9 & Acneiform Eruption & $3(1)$ & $\begin{array}{l}\text { Antiepileptic: } \\
\text { Antithyroid: }\end{array}$ & $\begin{array}{l}\text { Phenytoin } \\
\text { Carbimazole }\end{array}$ \\
\hline 10 & Dapsone Syndrome & $2(0.7)$ & Dapsone 2: & Dapsone \\
\hline 11 & Irritant Dermatitis & $2(0.7)$ & $\begin{array}{l}\text { Anti inflammatory: } \\
\text { Antiacneiform: }\end{array}$ & $\begin{array}{l}\text { Retinoids } \\
\text { Benzoyl Peroxide }\end{array}$ \\
\hline 12 & Hyperpigmentation & $2(0.7)$ & Antimicrobials 2: & Clindamycin, Tobramycin \\
\hline 13 & Phototoxic reaction & $2(0.7)$ & $\begin{array}{l}\text { Antimicrobials: } \\
\text { Diuretic: }\end{array}$ & $\begin{array}{l}\text { Doxycycline } \\
\text { Furosemide }\end{array}$ \\
\hline 14 & Allergic contact Dermatitis & $1(0.3)$ & Antimicrobials: & Ciprofloxacin \\
\hline 15 & Alopecia & $1(0.3)$ & Isotretinoin & \\
\hline 16 & Aphthous ulcer & $1(0.3)$ & NSAID: & Diclofenac \\
\hline 17 & Eczematous drug rash & $1(0.3)$ & Antidiabetic: & Repaglinide \\
\hline 18 & Erythema Nodosum & $1(0.3)$ & Antimicrobials: & Ciprofloxacin \\
\hline 19 & Purpuric Rash & $1(0.3)$ & Antimicrobials: & ATT \\
\hline 20 & Scarletiform Rash & $1(0.3)$ & Antiepileptic: & Phenytoin \\
\hline
\end{tabular}

Table 4: Most common CADRs- Nos. (\%) with most frequent Drug groups- Nos.: Age and sex wise distribution.

\begin{tabular}{|c|c|c|c|c|c|}
\hline \multicolumn{6}{|c|}{ Most common cutaneous ADRs Nos.(\%) with most frequent drug groups- Nos.: Age and sex wise distribution } \\
\hline $\begin{array}{l}0-18 \\
\text { Age } \\
\text { group }\end{array}$ & $\begin{array}{l}\text { Urticaria/Angioedema } \\
24(42.1 \%) \\
\text { Antimicrobials } 18 \\
\text { Antacid } 1\end{array}$ & $\begin{array}{l}\text { Generalised } \\
\text { Pruritis } 9(15.7 \%) \\
\text { Antimicrobials } 8 \\
\text { Haematinics 1 }\end{array}$ & $\begin{array}{l}\text { Morbiliform Rash } \\
7(12.2 \%) \\
\text { Antimicrobials } 7\end{array}$ & $\begin{array}{l}\text { Local Reaction } \\
7(12.2 \%) \\
\text { Antimicrobials } 7 \\
\text { Antiemetic } 1\end{array}$ & $\begin{array}{l}\text { Fixed Drug Eruption } \\
5(8.7 \%) \\
\text { Antimicrobials } 5\end{array}$ \\
\hline $\begin{array}{l}19-59 \\
\text { Age } \\
\text { group }\end{array}$ & $\begin{array}{l}\text { Urticaria/Angioedema } \\
72(37.1 \%) \\
\text { Antimicrobials } 32 \\
\text { NSAIDs16 }\end{array}$ & $\begin{array}{l}\text { Generalised } \\
\text { Pruritis } 35(18 \%) \\
\text { Antimicrobials } 25 \\
\text { NSAIDs } 4\end{array}$ & bials 22 & $\begin{array}{l}\text { Fixed Drug eruption } \\
24(12.3 \%) \\
\text { Antimicrobials } 11 \\
\text { Antacids } 7\end{array}$ & $\begin{array}{l}\text { orm Rash } \\
\text { robials } 8 \\
\text { ls } 2\end{array}$ \\
\hline $\begin{array}{l}60 \text { and }> \\
\text { Age } \\
\text { group }\end{array}$ & $\begin{array}{l}\text { Urticaria/Angioedema } \\
11(33.3 \%) \\
\text { Antimicrobials } 6 \\
\text { Diuretics } 2\end{array}$ & $\begin{array}{l}\text { Generalised } \\
\text { Pruritis 11(33.3\%) } \\
\text { Antimicrobials } 7 \\
\text { Antacids } 2\end{array}$ & $\begin{array}{l}\text { Fixed Drug Eruption } \\
8(24.2 \%) \\
\text { Antimicrobials } 7 \\
\text { NSAIDs } 1\end{array}$ & $\begin{array}{l}\text { Eczematous Drug } \\
\text { Rash } 1(3 \%) \\
\text { Antidiabetics } 1\end{array}$ & $\begin{array}{l}\text { Phototoxic Reaction } \\
1(3 \%) \\
\text { Diuretics } 1\end{array}$ \\
\hline Males & $\begin{array}{l}\text { Urticaria/Angioedema } \\
47(34.8 \%) \\
\text { Antimicrobials } 27 \\
\text { NSAIDs } 9\end{array}$ & $\begin{array}{l}\text { Generalised } \\
\text { Pruritis 26(19.2\%) } \\
\text { Antimicrobials } 21 \\
\text { NSAIDs } 9\end{array}$ & $\begin{array}{l}\text { Fixed Drug Eruption } \\
25(18.5 \%) \\
\text { Antimicrobials } 15 \\
\text { NSAIDs } 6\end{array}$ & $\begin{array}{l}\text { Local Reaction } \\
17(12.5 \%) \\
\text { Antimicrobials } 15\end{array}$ & $\begin{array}{l}\text { Morbiliform Rash } \\
7(5.1 \%) \\
\text { Antimicrobials } 5\end{array}$ \\
\hline Females & $\begin{array}{l}\text { Urticaria/Angioedema } \\
62(41 \%) \\
\text { Antimicrobials } 30 \\
\text { NSAIDs } 10\end{array}$ & $\begin{array}{l}\text { Generalised } \\
\text { Pruritis 29(19.2\%) } \\
\text { Antimicrobials } 19 \\
\text { NSAIDs 5 }\end{array}$ & $\begin{array}{l}\text { Local Reaction } \\
17(11.2 \%) \\
\text { Antimicrobials } 13 \\
\text { Antacids } 3\end{array}$ & $\begin{array}{l}\text { Morbiliform Rash } \\
13(8.6 \%) \\
\text { Antimicrobials } 10\end{array}$ & $\begin{array}{l}\text { Fixed Drug Eruption } \\
12(7.9 \%) \\
\text { Antimicrobials } 8 \\
\text { NSAIDs } 2\end{array}$ \\
\hline
\end{tabular}


Moreover they pose a significant threat to the health of the patients as CADRs may even be life threatening. A constant monitoring of CADRs is a must, since identification of potential ones and newer ones would pave way to prevent or avoid them.

As per the WHO causality criteria, most of the CADRs taken for analysis came under the probable causality, similar to the study done by Chatterjee et al. ${ }^{6}$ As far as the age wise distribution, most of them were observed in the adult age group population. Similar results were seen in other studies. ${ }^{4,13}$ This could be because of the fact that the health seeking behaviour of the adult age group is more when compared to their paediatric and geriatric counterparts.

In our study the females had a slightly higher incidence than the males with a ratio of 1:0.89, similar to the other studies conducted elsewhere. ${ }^{15-18}$

Among the drugs causing the CADRs, the most common drug groups involved were antimicrobials. This is similar to many studies conducted elsewhere..$^{3,5,18-22}$ The NSAIDs followed them as the next common drug groups to cause CADRs, similar to other studies. ${ }^{12,18}$ Among the antimicrobials ciprofloxacin was the most common drug involved followed by cefotaxime. This again was similar to the study conducted by Vijeya kumar et al and similar results were obtained from the study by Qayoom et al, where quinolones were followed by cephalosporins as the most common antimicrobial groups involved. ${ }^{18,19}$ This was in contrast to other studies where sulphonamides were the leading cause. ${ }^{12,13}$ The difference in the pattern of antimicrobials between different studies could be due to the differences in the physician's preferences in using various antimicrobials and the varied disease prevalence from region to region. ${ }^{4}$

In the present study, urticaria/angioedema was the most common CADR detected followed by generalised pruritis and fixed drug eruption. Similar results were obtained in one study, where urticaria was the leading CADR. ${ }^{23}$ This is different from the other studies where maculopapular rash was the leading cause and fixed drug eruption in some. ${ }^{4,5,13,18,22}$ The difference could be due to varied disease prevalence from place to place and the use of different kind of drugs for their appropriate management. In many of the studies describing CADRs, the most common CADRs were caused by antimicrobials. ${ }^{3,5,13,18,19,22}$ The reason for this could be due to the fact that antimicrobials are the most commonly used drugs among other drugs since infectious diseases are one of the most common ailment which patients present with, and apart from that they are also frequently used prophylactically both before and after surgical procedures. In many studies quinolones were the most common antimicrobials involved. ${ }^{18,19}$ The reason for this could be due to the fact that, quinolones being broad spectrum antimicrobials are the most frequently prescribed antimicrobials by clinicians.
Among the severe CADRs we had six cases of Stevens Johnson syndrome, of which 4 cases were due to antiepileptics and 2 were due to antimicrobials. There were six cases of Erythema multiforme, all were caused by antimicrobials. This widely correlates with many studies where anticonvulsants and antimicrobials were the frequently involved drugs in causing such severe CADRs. ${ }^{5,13,18}$

In the age wise distribution urticaria/angioedema was the most common CADRs in all the age groups, followed by generalised pruritis. The drugs most commonly involved in the most frequent CADRs in all the age groups were again found to be antimicrobials.

In the sex wise distribution the female sex had marginally more incidences of CADRs compared to males. In both the sexes the most common CADRs were urticaria/angioedema followed by generalised pruritis. In both the sexes, in all the frequent CADRs, the most common drug groups involved were again antimicrobials.

\section{CONCLUSION}

As CADRs are the most common ADRs among others, it is prudent to monitor them closely, as any change in pattern with older or newer agents can alert the health care personnel in instituting the appropriate prescription patterns, which can overall impact the quality of health care positively.

\section{ACKNOWLEDGEMENTS}

I would like to thank, the Pharmacovigilance Programme of India, Indian Pharmacopoeia Commission, Ghaziabad, India. I would also like to thank Dr. Lourdu Jafrin A, Dr. Priyadharsini R for their valuable support.

Funding: No funding sources

Conflict of interest: None declared

Ethical approval: The study was approved by the Institutional Ethics Committee

\section{REFERENCES}

1. Edwards IR, Aronson JK. Adverse drug reactions: definitions, diagnosis, and management. Lancet Lond Engl. 2000;356(9237):1255-9.

2. Uppal R, Jhaj R, Malhotra S. Adverse drug reactions among inpatients in a north Indian referral hospital. Natl Med J India. 2000;13(1):16-8.

3. Jhaj R, Uppal R, Malhotra S, Bhargava VK. Cutaneous adverse reactions in in-patients in a tertiary care hospital. Indian J Dermatol Venereol Leprol. 1999;65(1):14-7.

4. Pudukadan D, Thappa DM. Adverse cutaneous drug reactions: clinical pattern and causative agents in a tertiary care center in South India. Indian J Dermatol Venereol Leprol. 2004;70(1):20-4. 
5. Saha A, Das NK, Hazra A, Gharami RC, Chowdhury SN, Datta PK. Cutaneous adverse drug reaction profile in a tertiary care out patient setting in eastern India. Indian J Pharmacol. 2012;44(6):792-7.

6. Chatterjee S, Ghosh AP, Barbhuiya J, Dey SK. Adverse cutaneous drug reactions: a one-year survey at a dermatology outpatient clinic of a tertiary care hospital. Indian J Pharmacol. 2006;38(6):429-31.

7. Muehlberger N, Schneeweiss S, Hasford J. Adverse drug reaction monitoring- cost and benefit considerations. Part I: frequency of adverse drug reactions causing hospital admissions. Pharmacoepidemiol Drug Saf. 1997;6(3):S71-7.

8. Suh DC, Woodall BS, Shin SK, Hermes-De Santis ER. Clinical and economic impact of adverse drug reactions in hospitalized patients. Ann Pharmacother. 2000;34(12):1373-9.

9. Davies EC, Green CF, Taylor S, Williamson PR, Mottram DR, Pirmohamed M. Adverse drug reactions in hospital in-patients: a prospective analysis of 3695 patient-episodes. PloS One. 2009;4(2):e4439.

10. Pirmohamed M, James S, Meakin S, Green C, Scott AK, Walley TJ, et al. Adverse drug reactions as cause of admission to hospital: prospective analysis of 18820 patients. BMJ. 2004;329(7456):15-9.

11. Mani AR, Rajendran AD, Suresh B. Adverse drug reaction monitoring in secondary care hospital in south India. Br J Clin Phormacol. 2007;65:210-6.

12. Naldi L, Conforti A, Venegoni M, Troncon MG, Caputi A, Ghiotto E, et al. Cutaneous reactions to drugs. An analysis of spontaneous reports in four Italian regions. Br J Clin Pharmacol. 1999;48(6):83946.

13. Sharma VK, Sethuraman G, Kumar B. Cutaneous adverse drug reactions: clinical pattern and causative agents- a 6 year series from Chandigarh, India. J Postgrad Med. 2001;47(2):95-9.

14. Goettler M, Schneeweiss S, Hasford J. Adverse drug reaction monitoring--cost and benefit considerations. Part II: cost and preventability of adverse drug reactions leading to hospital admission. Pharmacoepidemiol Drug Saf. 1997;6(3):S79-90.
15. Bem JL, Breckenridge AM, Mann RD, Rawlins MD. Review of yellow cards (1986): report to the Committee on the Safety of Medicines. Br J Clin Pharmacol. 1988;26(6):679-89.

16. Moore N, Noblet C, Kreft-Jais C, Lagier G, Ollagnier $\mathrm{M}$, Imbs JL. (French pharmacovigilance database system: examples of utilization). Therapie. 1995;50(6):557-62.

17. Faich GA, Knapp D, Dreis M, Turner W. National adverse drug reaction surveillance: 1985. JAMA. 1987;257(15):2068-70.

18. Qayoom S, Bisati S, Manzoor S, Sameem F, Khan K. Adverse cutaneous drug reactions- a clinicodemographic study in a tertiary care teaching hospital of the Kashmir Valley, India. Arch Iran Med. 2015;18(4):228-33.

19. Vijeyakumar TM, Dhanraju MD. Description of Adverse Drug Reactions in a Multispeciality Teaching hospital. Int J Integr Med. 2013;1(26).

20. Camargo AL, Cardoso Ferreira MB, Heineck I. Adverse drug reactions: a cohort study in internal medicine units at a university hospital. Eur J Clin Pharmacol. 2006;62(2):143-9.

21. Samuel SA, Rajendran SD, Ebenezzar S, Jayaharan S, Azir P. Surveillance of adverse drug reactions at two multidisciplinary hospitals and an outpatient specialty clinic in India. Int $\mathbf{J}$ Pharm Pract. 2002;10(2):115-20.

22. Nandha R, Gupta A, Hashmi A. Cutaneous adverse drug reactions in a tertiary care teaching hospital: A North Indian perspective. Int J Appl Basic Med Res. 2011;1(1):50-3.

23. SDI, MM, NSM, Amutha A, I GJ, Rahman F. Pharmacovigilance of the cutaneous drug reactions in outpatients of dermatology department at a tertiary care hospital. J Clin Diagn Res JCDR. 2012;6(10):1688-91.

Cite this article as: Babu LN, Carounanidy U, Vasudevan KP, Sivagnanam G. Pattern of cutaneous adverse drug reactions at a tertiary care hospital in Southern India. Int J Basic Clin Pharmacol 2017;6:538-42. 